\title{
THE BLOOD ANTIQUITIES CONVENTION AND ASIAN CULTURAL PROPERTY. A REMEDY OR DISAPPOINTMENT? THE CASE OF CAMBODIA
}

The Council of Europe Convention on Offences relating to Cultural Property adopted on May 3, 2017, aka the "Blood Antiquities Convention" (hereinafter referred to as the "2017 Nicosia Convention"), is a legal reaction to the rising level of vandalism of cultural sites and illicit trade in cultural property, especially in the Middle East, in the recent decades. ${ }^{1}$ However, it is necessary to see the impact of this new instrument in the combat of crimes against any and all cultural property, including the heritage originating from the Far East. The following study aims at examining the chain of events illustrating crimes against Khmer cultural property in the $20^{\text {th }}$ century and the development of the legal framework fostering international cooperation in the field of cultural property protection and restitution as a way of argumentation for or against the adoption of the 2017 Nicosia Convention to combat crime against Asian cultural property.

The development of crimes against Asian cultural property is currently predominated by the occurrences in Syria or Afghanistan. However, the destruction of sites and illicit trafficking in cultural property is by no means a phenomenon restricted to that area. Especially in the turmoil of political changes and armed conflicts of the $19^{\text {th }}$ and $20^{\text {th }}$ century, Cambodia, South Korea, China and Japan have suffered irrecoverable cultural losses and, given the development and globalisation of the market and cultural institutions, objects looted under these past circumstances are still emerging. While the instances of plunder in the $19^{\text {th }}$ century pose no legal discussion due to the validity of the right of spoil at the time, e.g. the South Korea vs France case over Korean manuscripts looted in 1866 by the French, ${ }^{2}$ the cases of illicit export of looted property in the post-1970 world certainly do.

\footnotetext{
1 M.M. Bieczyński, The Nicosia Convention 2017: A New International Instrument Regarding Criminal Offences against Cultural Property, "Santander Art and Culture Law Review" 2017, no. 2/3, p. 256.

2 R. Contel, A.L. Bandle, M.A. Renold, Affaire Manuscrits Coréens - France et Corée du Sud, https://plone.unige.ch/art-adr/cases-affaires/affaire-manuscrits-coreens-2013-france-et-coreedu-sud-1/\#F14 (accessed: 24.11.2018).
} 


\section{The United States v. a $10^{\text {th }}$ Century \\ Cambodian Sandstone Sculpture}

The first publicly discussed incident of looting Khmer art emerged in 1924 when none other than the André Malraux, an art theorist and a later France's minister of cultural affairs, decided to sell "souvenirs" he and his wife had brought from their trip to Angkor. ${ }^{3}$ The development of illicit trafficking in Cambodia's cultural heritage followed the Vietnamese invasion of Cambodia and involved refugee groups in Thailand trained to pillage Cambodia's ancient sites for the purpose of transferring dismembered cultural property abroad to reach the art market in Bangkok and, subsequently, Europe or the United States. ${ }^{4}$

The United States v. a $10^{\text {th }}$ Century Cambodian Sandstone Sculpture case (hereinafter referred to as the U.S. v. Cambodian Sculpture) ${ }^{5}$ serves as an example of such occurrences and reflects the need to strengthen international cooperation in the combat of crimes against cultural property, regardless of the ratification of previous instruments regulating this scope. Cambodia ratified the 1954 Convention for the Protection of Cultural Property in the Event of Armed Conflict with Regulations for the Execution of the Convention (hereinafter referred to as the "Hague Convention") in 1962. After the increase of the transfer of Cambodian "cultural material" to the United States in late $1960 \mathrm{~s}^{6}$, the Kingdom adopted the 1970 UNESCO Convention on the Means of Prohibiting and Preventing the Illicit Import, Export and Transfer of Ownership of Cultural Property (hereinafter the “1970 UNESCO Convention") in 1972.

In spite of these efforts, during the period of unrest caused by the civil war and political turmoil between the mid-late 1960s and 1979, cultural heritage sites in Cambodia suffered a widespread looting by a "looting network" involving "local teams of looters" removing artifacts from original locations and transporting them to "dealers in Khmer artifacts located in Thailand." The Koh Ker Warrior, or the Duryodhana, the defendant in the U.S. v. Cambodian Sculpture case, had been broken off its original pedestal at the Prasat Chen temple in Koh Ker, an

3 M. Lafont, Pillaging Cambodia: The Illicit Traffic in Khmer Art, Jefferson 2004, p. 2.

4 Ibidem.

5 United States v. a 10th Century Cambodian Sandstone Sculpture, 12 Civ. 2600 (GBD) (S.D.N.Y. Mar. 28, 2013), https://casetext.com/case/united-states-v-a-10th-century-cambodian-sandstonesculpture (accessed: 25.11.2018).

${ }^{6}$ N. Brodie, J. Doole, The Asian Art Affair: US Art Museum Collections of Asian Art and Archaeology as quoted in: T. Davis, The Lasting Impact of the United States vs. Cambodian Sculpture [in:] Countering Illicit Traffic in Cultural Goods. The Global Challenge of Protecting the World's Heritage, ed. F. Desmarais, Paris 2015, p. 99.

T. Davis, The Lasting Impact..., p. 99. 
archaeological site located in northern Cambodia, ${ }^{8}$ and looted around 1972, in the midst of the war. It was removed from the country under communist control, therefore, most probably, by the Khmer Rouge themselves to, supposedly, finance their military activity, thus gaining the status of a "blood antiquity." The "network" smuggled the sculpture in parts ("the head of the statue was removed and transported first, followed by the torso" $)^{10}$ to a dealer in Bangkok who transferred it to a collector of Khmer antiquities who supposedly knew that the statue of the warrior had been stolen. ${ }^{11}$

The piece entered the official market in 1975, when the collector sold the statue to a Belgian businessman through a British auction house. ${ }^{12}$ As the claimants later asserted, the purchaser acted in good faith, however, "the court reminded that good faith was not presumed under British law."13 Upon the owner's death in 2000, the statue was transferred to his wife who, as a result of discussions with Sotheby's in 2010 , consigned the statue to the auction house. ${ }^{14}$ Sotheby's obtained an invoice of the sale in 1975 and consulted the collector, as the "original seller" to import the statue to the United States. ${ }^{15}$ Interestingly, in 1999, the U.S. Customs Regulations were amended and the so-called "emergency import restrictions" on "certain Khmer stone archeological material of the Kingdom of Cambodia" was imposed. It excludes the property accompanied by "export permits issued by the Government of the Kingdom of Cambodia, or by documentation demonstrating that they were out of the country before December 2, 1999." "16

In 2003, Cambodia and the U.S., acting pursuant to the 1970 UNESCO Convention, entered into a bilateral agreement (a memorandum of understanding) to, "reduce the incentive for pillage of certain categories of irreplaceable archaeological material representing the Khmer culture of Cambodia from approximately the $6^{\text {th }}$ century through the $16^{\text {th }}$ century A.D. and including objects comprised of stone,

${ }^{8}$ L. Henderson, The Duryodhana Dilemma: United States v. a 10th Century Cambodian Sandstone Sculpture and a Proposed Code of Ethics-Based Response to Repatriation Requests for Auction Houses, "University of Pennsylvania Law Review” 2014, no. 163/249, p. 252.

9 T. Davis, The Lasting Impact..., p. 96.

10 United States...

11 E. Velioglu, A.L. Bandle, M.A. Renold, Case Note Khmer Statue - Cambodia and Sotheby's and the United States, https://plone.unige.ch/art-adr/cases-affaires/khmer-statue-2013-cambodiaand-sotheby2019s-and-the-united-states/case-note-khmer-statue-2013-cambodia-and-sotheby2019s-and-the-united-states/view (accessed: 26.11.2018).

12 Ibidem, p. 2.

13 Ibidem, p. 6.

14 United States...

15 Ibidem.

16 Cultural Heritage Center - Cambodia, https://eca.state.gov/cultural-heritage-center/cultural-property-protection/bilateral-agreements/cambodia (accessed: 26.11.2018). 
metal (...), and ceramic"17 - it is worth to remind ourselves that the Warrior sculpture falls both under the object categories listed in the 1999 import restrictions and the scope of the 2003 memorandum. In preparation of the sale, after the conflicting opinions of experts contracted by Sotheby's for the purpose of authenticity research and writing an entry on the statue, it was confirmed to had been forcefully removed from its original location and stolen, however, one of the experts advised to sell it as "it did not appear as if Cambodia, as a general practice, was requesting the return of looted Cambodian art and artifacts."18

In the end, the auction house sent a message to the Cambodian Ministry of Culture informing about its intent to sell the sculpture, however, the Ministry never replied and it was only upon its appearance in the auction catalogue that the Secretary General of the Cambodian National Commission for UNESCO requested to withdraw the piece from the sale and to support its return to Cambodia. ${ }^{19}$ Despite the withdrawal of the sculpture from the auction, Sotheby's retained its possession which lead Cambodia to turn to the United States for the support in its recovery and the U.S. government eventually filed a civil forfeiture action against the defendant in rem. ${ }^{20}$ It was charged that the warrior was looted property introduced into the U.S. contrary to law. ${ }^{21}$ After negotiations, including an unsuccessful private purchase proposal by a collector interested in donating the sculpture to Cambodia, and amended complaints presenting new evidence, the case ended with an out-of-courtsettlement reached by the U.S. government and the claimants and the subsequent return of the sculpture to Cambodia. ${ }^{22}$ Interestingly, the ownership was claimed by Cambodia without filing a claim for restitution. ${ }^{23}$

On the one hand, this case reflects the deficiency of international law, on the other - the need to strengthen international cooperation with regard to the protection and licit traffic of cultural property, be it on legal or purely ethical grounds. The need of implementing a uniform code of ethics to prevent such phenomena has already been noted, e.g. according to Lauren Henderson, "auction houses should look to the International Council of Museums' (ICOM) Code of Ethics for Museums as a model for fashioning their own code of ethics." ${ }^{24}$ Interestingly, during the timeline of the warrior case, Cambodia managed to regain other looted cultural

\footnotetext{
17 Memorandum of Understanding Between the United States of America and Cambodia, https://eca.state.gov/files/bureau/cambodia_tias.pdf (accessed: 25.11.2018).

18 E. Velioglu, A.L. Bandle, M.A. Renold, Case Note Khmer Statue..., p. 3.

Ibidem.

20 L. Henderson, The Duryodhana Dilemma..., p. 254.

21 T. Davis, The Lasting Impact..., p. 96.

22 E. Velioglu, A.L. Bandle, M.A. Renold, Case Note Khmer Statue..., p. 5.

23 Ibidem.

24 L. Henderson, The Duryodhana Dilemma..., p. 251.
} 
property thanks to its cooperation with ICOM, ${ }^{25}$ e.g. a Khmer head sold in Hong Kong in the 1980s, retraced on the American market in 1996, and, subsequently, returned to Cambodia in 1997, therefore the role of international cooperation is unquestionable in the endeavor to promote the importance of preservation of cultural heritage. Secondly, despite the partial effectiveness of legal instruments in this matter, the adoption of any new acts should be taken into consideration.

\section{The 2017 Nicosia Convention and Asian Cultural Property}

The 2017 Nicosia Convention, is a result of the revision of its predecessor, the 1985 Delphi Convention, that never reached the minimum number of ratifications and, therefore, remained invalid. The new 2017 Convention, currently open for signature, is a new hope in strengthening the framework of cooperation for combating crimes against cultural property. It seeks to deliver "a complimentary criminal law framework that applies to illicit cultural objects." ${ }^{26}$ Its main development is the focus on particular crimes against cultural property, a broadened scope of protection and a shift in regulating the obligation of exercising due diligence.

The 2017 Nicosia Convention utilizes the term "cultural property" in respect to both movable and immovable property "classified, defined or specifically designated by any Party to this Convention [i.e. the 2017 Nicosia Convention"] or to the 1970 UNESCO Convention on the Means of Prohibiting and Preventing the Illicit Import, Export and Transfer of Ownership of Cultural Property." In accordance to the scope and use of terms in Chapter I of the 2017 Convention, the efforts to protect property targets both national and foreign assets, as identified by the 1970 UNESCO Convention, therefore, the scope of the new instrument stretches beyond its states parties and also applies to "cultural property classified, defined, or specifically designated by any Party to the 1970 UNESCO Convention." 27

Criminal law instances are specified in Chapter II. It lists such acts as theft, unlawful excavation and removal, illegal importation and exportation, forging (and tampering with) documents regarding cultural property, destruction and damage of cultural property or aiding and abetting the commission of a criminal offence. ${ }^{28}$

25 Ecole française d'Extrême-Orient, International Council of Museums, One Hundred Missing Objects. Looting in Angkor, 2nd ed., Paris 1997.

26 D. Fincham, The Blood Antiquities Convention as a Paradigm for Cultural Property Crime Reduction, “Cardozo Arts \& Entertainment Law Journal” 2019, vol. 37, no. 2, p. 301.

27 M.M. Bieczyński, The Nicosia Convention 2017..., p. 266.

28 Interestingly, the commission of an offence "in the framework of a criminal organisation" constitutes mere "aggravating circumstances." 
Therefore, it is the only instrument proposing a comprehensive, and updated (including instances of trading antiquities online, through social media, and the Deep Web) ${ }^{29}$ list of crimes against cultural property, therefore its role in the development of new uniform standards in this area is unquestionable.

Pursuant to Article 7 regulating the acquisition of property, due diligence is imposed on the buyer. It specifies, that each party shall:

a) ensure that the acquisition of movable cultural property that has been stolen in accordance with Article 3 of this Convention or has been excavated, imported or exported under circumstances described in Articles 4, 5 or 6 of this Convention constitutes a criminal offence under its domestic law where the person knows of such unlawful provenance, and

b) consider taking the necessary measures to ensure that the conduct described in paragraph 1 of the present article constitutes a criminal offence also in the case of a person who should have known of the cultural property's unlawful provenance if he or she had exercised due care and attention in acquiring the cultural property.

Therefore, the identification of the occurrence of a bona fide purchase is directed to local legislation - parties may be "allowed to go beyond this minimum requirement by also criminalising non-intentional acts," however, bearing in mind the available development in this field, the due diligence measures proposed by the 1995 UNIDROIT Convention may serve as a common point of reference. According to the provision of Article 20 of the 2017 Nicosia Convention, it imposes the obligation to "introduce due diligence provisions for art and antiquity dealers, auction houses and others involved in the trade in cultural property and introduce an obligation to establish records of their transactions. These records should be made available to the competent authorities in accordance with domestic law." As an example of satisfying this obligation, the Cambodian Law of January 25, 1996 on the Protection of Cultural Heritage $^{30}$ introduced the concept of "trading permits" resulting in the establishment of "authorized dealers" in antiquities under Section 6 - pursuant to Article 33, "all authorized dealers shall be bound by the following obligations:"

a) to display a notice at the entrance to their sales premises stating they are authorized to sell cultural property;

b) not to place any cultural property intended for sale outside the premises in which they are authorized to conduct their activity;

c) to keep detailed records of the cultural property that they possess, and of day-to-day sales and purchases;

29 Explanatory Report to the Council of Europe Convention on Offences relating to Cultural Property, https://rm.coe.int/CoERMPublicCommonSearchServices/DisplayDCTMContent?documentId=0900001680710437 (accessed: 26.11.2018).

30 Translation available from WIPO lex, https://www.wipo.int/wipolex/en/text.jsp?file_ id=181713 (accessed: 24.11.2018). 
d) to make the records mentioned in (c) available to inspectors whenever requested to do so;

e) to display in a prominent position on the sales premises the provisions of this law concerning the export of cultural objects;

f) to show any cultural property in their possession to inspectors during an inspection;

g) to provide inspectors with a photograph of any cultural object in their possession, or to allow them to photograph the cultural object if they so wish;

h) to assist inspectors and facilitate their work during an inspection;

i) to inform the competent authority of any removal of sales premises to another site.

Despite the legislation at a national level, it is worth to mention that Cambodia signed the 1995 UNIDROIT Convention on Stolen or Illegally Exported Cultural Objects in 1995 and despite the fact that its ratification took place in 2002, the National Assembly of the Kingdom of Cambodia strengthened the protection of cultural heritage through adopting the Law on the Protection of Cultural Heritage in 1996, "in accordance with international best practices," 31 therefore the impact of the 1995 UNIDROIT Convention was evident at that time, however, the regulation of criminal activity of e.g. "international crime rings dealing in cultural property" remained out of its scope, therefore a new instrument was already needed. ${ }^{32}$

As opposed to the unsuccessful Delphi Convention 1985, the 2017 Nicosia Convention is open to signature and ratification by non-members of the Council of Europe - e.g. Japan and Mexico - and has already been ratified by the latter. However, it is unclear whether the interest of Japan in drafting the convention echoes in the region. Bearing in mind the development of crimes against cultural property referred to in this study, the adoption of any new instrument enforcing the protection of cultural assets is of high significance and should be taken into account due to its role in fostering the cooperation in the combat of crimes against cultural assets by acknowledging common principles of protection and fair trade.

\section{Conclusion}

Cambodia has suffered an irreversible loss in cultural property. Despite its efforts to ratify all major international law instruments regulating the protection of cultural

\footnotetext{
31 T. Davis, The Lasting Impact..., p. 98.

32 Cf. C. Armbrüster et al., Study on Preventing and Fighting Illicit Trafficking in Cultural Goods in the European Union by the CECOJI-CNRS - UMR 6224, Contract No. Home/2009/ ISEC/PR/019-A2, Final Report - October 2011 as quoted in: M.M. Bieczyński, The Nicosia Convention $2017 \ldots$, p. 262.
} 
heritage, i.e. the 1954 Convention for the Protection of Cultural Property in the Event of Armed Conflict, the 1970 UNESCO Convention on the Means of Prohibiting and Preventing the Illicit Import, Export and Transfer of Ownership of Cultural Property, and the 1995 UNIDROIT Convention on Stolen or Illegally Exported Cultural Objects, the offences against its cultural property persisted throughout the $20^{\text {th }}$ century, and new evidence still emerges. The 2017 Nicosia Convention on Offences relating to Cultural Property seems to possess all necessary features to establish a common legal framework for the combat of criminal activity against heritage and is open to non-members of the Council of Europe. The need to adopt a new instrument of an international character to enforce the cooperation to foster the protection and return of Asian cultural property is evident, however, the question whether its effectiveness stretches beyond its marketing function remains open and may be answered only upon its entry into force.

\section{STRESZCZENIE}

\section{KONWENCJA Z NIKOZJI A AZJATYCKIE DOBRA KULTURY - ROZWIAZZANIE CZY ROZCZAROWANIE? PRZYKXAD KAMBODŻY}

Konwencja Rady Europy o przestępczości przeciwko dobrom kultury (konwencja z Nikozji) została przyjęta 3 maja 2017 r. Bezpośrednią przyczyna jej opracowania stały się wzmożone zniszczenia na Bliskim Wschodzie i nielegalny handel dobrami kultury, szczególnie pochodzącymi z tego obszaru geograficznego, jednak należy przypomnieć o potrzebie rozbudowania środków międzynarodowej współpracy w zwalczaniu podobnych zjawisk dotykających również dobra kultury z Dalekiego Wchodu.

Losy rzeźby Wojownika z Koh Ker opisane w niniejszym artykule stanowia przykład nielegalnego wywozu i handlu kambodżańskimi dobrami kultury. Warto zaznaczyć, że wiele podobnych obiektów nadal nie zostało zidentyfikowanych i może być dopuszczonych do obrotu. Pomimo niezadowalających efektów ratyfikacji wszystkich głównych aktów prawa międzynarodowego w zakresie ochrony dóbr kultury przez Kambodżę należy zwrócić uwagę na nowe możliwości w tym obszarze.

Konwencja z Nikozji stanowi istotny element walki z przestępstwami przeciwko dziedzictwu. Jest otwarta również dla państw nieczłonkowskich, jak chociażby Japonia, której przedstawiciele uczestniczyli w opracowaniu dokumentu, zatem przystapienie do niej powinno zostać rozważone przez pozostałe kraje z regionu. 